\title{
Concordance and discordance of sequence survey methods for molecular epidemiology
}

Eduardo Castro-Nallar, Nur A. Hasan, Thomas A. Cebula, Rita R. Colwell, Richard A. Robison, W. Evan Johnson, Keith A. Crandall

The post-genomic era is characterized by the direct acquisition and analysis of genomic data with many applications including enhancing the understanding of microbial epidemiology and pathology. However, there are a number of molecular approaches to survey pathogen diversity and the impact of these different approaches on parameter estimation and inference are not entirely clear. We sequenced whole genomes of bacterial pathogens, Burkholderia pseudomallei, Yersinia pestis, and Brucella spp. (60 new genomes), and combined them with 55 genomes from GenBank to address how different molecular survey approaches (whole genomes, SNPs, and MLST) impact downstream inferences on molecular evolutionary parameters, evolutionary relationships, and trait character associations. We selected isolates for sequencing to represent temporal, geographic origin, and host range variability. We found that substitution rate estimates vary widely among approaches, and that SNP and genomic datasets yielded different but strongly supported phylogenies. MLST yielded poorly supported phylogenies, especially in our low diversity dataset, i.e., Y. pestis. Trait associations showed that B. pseudomallei and $Y$. pestis phylogenies are significantly associated with geography, irrespective of the molecular survey approach used, while Brucella spp. phylogeny appears to be strongly associated with geography and host origin. We contrast inferences made among monomorphic (clonal) and non-monomorphic bacteria, and between intra- and interspecific datasets. We also discuss our results in light of underlying assumptions of different approaches. 
2 Eduardo Castro-Nallar ${ }^{*}$, Nur A. Hasan ${ }^{2,3}$, Thomas A. Cebula ${ }^{2,4}$, Rita R. Colwell ${ }^{2,3,5}$,

3 Richard A. Robison ${ }^{6}$, W. Evan Johnson ${ }^{7}$ and Keith A. Crandall ${ }^{1}$

$4 \quad{ }^{1}$ Computational Biology Institute, George Washington University, Ashburn, VA 20147, USA;

$5 \quad{ }^{2}$ Cosmos ID, College Park, MD, USA;

$6 \quad{ }^{3}$ University of Maryland Institute for Advanced Computer Studies, University of Maryland, College

7 Park, MD, USA;

$8 \quad{ }^{4}$ Department of Biology, Johns Hopkins University, Baltimore, MD, USA;

$9{ }^{5}$ Bloomberg School of Public Health, Johns Hopkins University, Baltimore, MD, USA;

$10{ }^{6}$ Department of Microbiology and Molecular Biology, Brigham Young University, Provo, UT, USA;

$11{ }^{7}$ Division of Computational Biomedicine, Boston University School of Medicine, Boston, MA, USA

$12{ }^{*}$ Corresponding author: Eduardo Castro-Nallar, ecastron@gwu.edu, (571) 553-0146

13 Subject Areas: genomics, evolutionary studies, microbiology

14 Keywords: genetic diversity, SNP, genome, MLST, bacteria 
Introduction

17 Genomic data coupled with phylogenetic methods have enhanced the ability to track infectious disease

18 epidemics through space and time (Baker et al. 2010). For example, studies have tracked and

19 characterized epidemics occurring at different geographic scales, across local, regional, global, and

20 even historical scales; investigating multidrug-resistant Staphylococcus aureus in hospital settings (Kos

21 et al. 2012; Köser et al. 2012), inferring continental origins of food pathogens (Goss et al. 2014),

22 explaining seasonal influenza dynamics (Lemey et al. 2014), and ancient oral pathogens (Warinner et

23 al. 2014), respectively. Such studies provide valuable information regarding migration rates,

24 directionalities of spread, unique variants, genetic diversity, and drug resistance, as well as informing

25 policy-makers about infection patterns associated with human activities (Bos et al. 2011; Morelli et al.

26 2010; Zhang et al. 2010). Accordingly, applications of analytical tools to large datasets are abundant in

27 clinical pathology, bioforensics, biosurveillance, and molecular epidemiology (Reimer et al. 2011;

28 Wilson et al. 2013).

Whole-genome sequencing (WGS) has become an affordable approach for such studies

30 (Bertelli \& Greub 2013; Chen et al. 2013; Cornejo et al. 2013; Croucher et al. 2013; Pérez-Lago et al.

31 2013; Sheppard et al. 2013; Wielgoss et al. 2013). New technologies make it possible to compile

32 datasets that were not even dreamed of twenty years ago (Chewapreecha et al. 2014; Marttinen et al.

33 2012; Nasser et al. 2014; Sheppard et al. 2013) which, in turn, is prompting scientists to ask new

34 questions regarding pathogen distribution, diversity, identification, origin, and phenotype (Butler et al.

35 2013; Castillo-Ramirez et al. 2012; Grad \& Waldor 2013; Holt et al. 2012; Hong et al. 2014; Spoor et

36 al. 2013).

Because there are now a variety of molecular survey approaches: whole genome sequencing

38 (WGS), multi-locus sequence typing (MLST), and single nucleotide polymorphism (SNP) data, with

39 different costs and resolution abilities, we explored the impact of these different approaches on 
40 inferences of population dynamics, transmission patterns, and parameter estimation. For instance,

41 tracking the origin of bioterrorism agents depends on identifying diagnostic mutations, as in the

42 anthrax attacks of 2001 (Read et al. 2002), or accurately identifying the subspecies of origin (Hong et

43 al. 2014), and understanding the extent to which sampling strategy and choice of molecular survey

44 approach affects temporal and spatial inferences.

45 Here, we set out to investigate how molecular survey approaches compare, using three select

46 agents as models, namely Yersinia pestis (causative agent of plague), Burkholderia pseudomallei

47 (causative agent of melioidosis), and Brucella spp. (febrile disease). These bacterial species are

48 relevant from health and biosecurity perspectives, and there exists a sizable amount of genomic and

49 supporting information (date of collection, geographic location, and host) for them. Also, they allow

50 for interesting contrasts including comparing intraspecific datasets (Y. pestis v. B. pseudomallei), one

51 from monomorphic bacteria (clonal), and the other from polymorphic bacteria, as well as interspecific

52 comparisons (Y. pestis and B. pseudomallei vs. Brucella spp.)

53 Thus, we present and analyze new draft genomic sequences for 20 Brucella spp., 20 Y. pestis,

54 and $20 \mathrm{~B}$. pseudomallei isolates, which we combine with publicly available genomes (totaling 115

55 genomes) to compare inferences on evolutionary relationships, dates and rates, and geographic and

56 host structure. Do molecular survey approaches, as currently practiced, produce incongruent

57 inferences? We performed a comparison with real-world examples using species that represent genetic

58 diversities of relevance to clinical molecular epidemiology. We applied different molecular survey

59 approaches (WGS, SNPs, MLST) to evaluate whether these can recover equivalent evolutionary

60 relationships, evolutionary rates and divergence dates, and whether phylogenies inferred with these

61 approaches represent equivalent geographic and host structures. 


\section{Methods}

64 Strain selection and sequencing

65 DNA was isolated from 20 strains of Burkholderia pseudomallei, Yersinia pestis, and Brucella spp.

66 from the Brigham Young University Select Agent Archive. Samples were selected for sequencing to

67 provide a range of 1) time of isolation, 2) geographic spread, and 3) host association (Table 1). DNA

68 isolation followed standard protocols for select agents and was conducted at the Brigham Young

69 University BSL-3 facility. All DNA preparations received a Certification of Sterility (10\% of the final

70 DNA preparation from each isolate was plated for sterility on appropriate agar, and after a minimum of

71 five days of incubation at $37^{\circ} \mathrm{C}$, the samples showed no growth, indicating they contained no viable

72 organisms) before being prepared for sequencing.

73 The DNA samples were prepared for multiplexed (single-end, 82 cycles) sequencing using

74 Illumina GAIIx genome analyzer (Illumina Inc., San Diego, CA). For each isolate, genomic library

75 preparations were generated using Nextera DNA Sample Prep Kit. Post library quality control and

76 quantification was done using BioAnalyzer 2100 high-sensitivity chips and KAPA SYBR FAST

77 Universal 2X qPCR Master Mix. Post processing of reads was performed by the RTA/SCS v1.9.35.0

78 and CASAVA 1.8.0. Reads were trimmed to the Q30 level using CLCBio's quality_trim program,

79 CutAdapt v0.95 was used to excise adapter and transposon contamination.

80 All sequencing run data and metadata were deposited in the Sequence Read Archive (SRA)

81 under three projects, SRP022877, SRP022862, and SRP023117 for Y. pestis, Brucella spp., and B.

82 pseudomallei, respectively.

\section{Dataset Collection}

85 Short reads were quality filtered (average read quality $>30$ Phred) and mapped against reference 86 genomes employing the Burrows-Wheeler Transform algorithm, as implemented in SOAP (Li et al. 
87 2008). The resulting SAM/BAM files were filtered for duplicate reads that might have arisen by PCR,

88 and consensus sequences were called in Geneious 6.1.6 (Kearse et al. 2012; Li et al. 2009). We

89 additionally retrieved full genomes along with host, collection date, and country of origin metadata for

90 B. pseudomallei (11), Brucella spp. (18) and Y. pestis (26) from GenBank, GOLD, IMG, Patric, Broad

91 Institute, and Pathema databases and resources totaling 115 genomes (Table 1; geographic distribution

92 in Suppl. Map) (Benson et al. 2010; Brinkac et al. 2010; Gillespie et al. 2011; Liolios et al. 2008;

93 Markowitz et al. 2012). From the assembled genomes we derived all datasets as described below.

94 Multi-locus sequence type markers for B. pseudomallei, namely ace, gltB, gmhD, lepA, lipA,

$95 n a r K$, and $n d h$ were retrieved from the PubMLST database (http://bpseudomallei.mlst.net). For

96 Brucella spp., we resorted to markers used by Whatmore et al., i.e., gap, $\operatorname{aroA}, \operatorname{glk}, d n a K, \operatorname{gyr} B, \operatorname{trp}$,

97 cobQ, omp25, and int-hyp (Whatmore et al. 2007). Likewise, for Y. pestis we obtained markers from

98 PubMLST (Yersinia spp.; http://pubmlst.org/yersinia/) aarF, dfp, galR, glnS, hemA, rfaE, and speA. In

99 addition, we obtained markers from Achtman (1999) ( $\operatorname{ms} A, \operatorname{gln} A, \operatorname{man} B, \operatorname{thr} A, \operatorname{tmk}$, and $\operatorname{trpE})$ and

100 from Revazishvili (2008) (16S rDNA, gyrB, yhsp, psaA and recA). We created a custom BLAST

101 (Altschul et al. 1990) database with our new genome sequences combined with the publicly available 102 genomes for all three species groups.

103 We created datasets based on SNPs by searching for $k$-mer $=25$ (SNP on position 13) among 104 unaligned genomes, as implemented in kSNP 2.0 (Gardner \& Hall 2013; Gardner \& Slezak 2010). We 105 chose this implementation because it does not depend on arbitrarily selecting a reference genome, it 106 can take draft and unassembled sequence data (including low-coverage genomes), and it is fast and 107 widely used in epidemiological studies (Epson et al. 2014; Pettengill et al. 2014; Raphael et al. 2014;

108 Timme et al. 2013). Briefly, the optimal k-mer size was estimated using Kchooser, which identifies 109 threshold value of $k$ for which non-unique $k$-mers are the result of real genome redundancy, not chance.

110 We kept all SNPs that were shared among all taxa in a given dataset (core SNP subset), which were 
111 used to build matrices for downstream analyses. The matrices used contained only variable bi-allelic 112 sites from non-overlapping $k$-mers and their size is described below (Table 2).

113 We created full genome datasets by aligning complete genome sequences in Mauve 2.3.1

114 (Darling et al. 2010) and then using the resulting multiple sequence alignment directly and/or reduced

115 for phylogenetic inference. The reduced full genome dataset consisted of all Locally Collinear Blocks

116 (LCBs) detected by Mauve that were greater than $10 \mathrm{~Kb}$ and randomly subsampled up to a total of 300

$117 \mathrm{~Kb}$ present across all taxa in a given dataset.

119 Diversity and Phylogenetic Analyses

120 We measured genetic diversity as the substitution rate-scaled effective population size $\Theta$ for all 121 molecular survey approaches (MLST, SNP, WGS), as implemented in the 'pegas' package in R 122 (Paradis 2010). We inferred phylogenies, both with and without assuming a molecular clock. Clock 123 phylogenies were inferred using Bayesian Inference (BI) and Markov Chain Monte Carlo (MCMC) 124 simulations as implemented in Beast 1.7.5 (restricting the analysis to those sequences with recorded 125 dates) and using the Beagle library to speed up analysis (Ayres et al. 2012; Drummond et al. 2012). We 126 assumed a General Time Reversible (GTR) substitution model for all three data approaches with a 127 discrete gamma distribution (4 categories) to model rate heterogeneity (MLST datasets were 128 partitioned by gene with a model fit per gene; rate heterogeneity was not modeled for SNP datasets).

129 We unsuccessfully tried to partition the genome dataset by gene, but phylogenetic inference did not 130 reach convergence. Briefly, MCMC simulations were run until a single chain reached convergence, as 131 diagnosed by its trace and ESS values ( $>400$; ranging from $2 \mathrm{E}^{8}$ to $2 \mathrm{E}^{9}$ steps; $10 \%$ burnin) in Tracer 1.5 132 (http://tree.bio.ed.ac.uk/software/tracer/) and tree distributions were summarized in TreeAnnotator 1331.7 .5 (10-20\% of trees were discarded as burnin). The molecular clock (strict clock model) was 
134 calibrated using isolate collection dates and a uniform distribution (from 0 to 1 ) as clock prior. We also 135 used BI for non-clock phylogenies as implemented in MrBayes 3.2 (Ronquist et al. 2012) where we ran

1368 chains ( 6 heated), $2 \mathrm{E}^{7}$ generations each. As in the clock phylogenies, we used visual inspection of the

137 traces as well as the average standard deviation of split frequencies to assess convergence. All trees 138 were rooted by using outgroups (Yersinia pseudotuberculosis IP31758, Ochrobactrum anthropic, and 139 Burkholderia thailandensis E264).

140 In order to compare tree topologies, we applied two topology metrics, Robinson-Foulds (RF, 141 Robinson \& Foulds 1981) and Matching Splits Clusters (MC, Bogdanowicz \& Giaro 2012) to compare 142 topologies across different molecular survey approaches and among chromosomes as implemented in 143 TreeCmp (Bogdanowicz et al. 2012). We also assessed to what extent phylogenies and traits (host 144 range, sample collection site, and sampling date) were correlated by Bayesian Tip-Significance testing 145 by estimating the Association Index (AI, Wang et al. 2001) and Parsimony Score (PS, Slatkin \& 146 Maddison 1989) as implemented in BaTs (Parker et al. 2008). Figures were plotted using ggplot2 147 (Wickham 2009) and APE (Paradis et al. 2004) packages, and high posterior density (HPD) intervals 148 were estimated using TeachingDemos package (Snow \& Snow 2013).

\section{Results and Discussion}

151 Sequencing technologies and statistical phylogenetic methods are arming researchers with powerful 152 tools to track infectious agents over space and time with unprecedented resolution (Holt et al. 2012; 153 Lewis et al. 2010). However, with multiple molecular survey approaches and a battery of analytical 154 methods, it is not clear how these interact.

155 Using 115 genomic sequences (60 this study +55 GenBank), we compared inferences 156 regarding genetic diversity, substitution rates and node ages, tree topologies, structure and phylogenies 157 inferred from different molecular survey approaches. We use the term "molecular survey approaches" 
158 to refer to either MLST, SNP, or WGS approaches, and the term "species datasets" or simply 'dataset'

159 to refer either to B. pseudomallei, Brucella spp. or Y. pestis sequence data belonging to any of these

160 species/genera. Given the difficulty of current algorithm implementations in reading and analyzing

161 whole bacterial genomes, we decided to randomly sub-sample core homologous regions to compile

162 genomic data that we termed "genome" (see Methods for details).

163

164 Diversity and datasets

165 Datasets sizes varied in length by data approach, species, and genomic partition (chromosome I/II).

166 Notably, we intended to include as many genes as possible for the MLST schemes, which resulted in

167 partitioned datasets ranging from 7 to 18 genes. In the case of $Y$. pestis, the MLST dataset constituted a

168 larger dataset than the SNP dataset due to the low variability in this species. The interspecific dataset,

169 i.e., Brucella spp., rendered the smallest dataset for all data approaches (least number of sites) as

170 opposed to intraspecific datasets (Y. pestis; B. pseudomallei) that ended up being one or two orders of

171 magnitude longer (Table 2; square brackets).

172 In order to characterize present genetic diversity of our datasets, we estimated effective

173 population size using a segregating sites model $(\Theta$; Watterson's theta) and nucleotide diversity $(\pi)(\mathrm{Nei}$

174 1987; Paradis 2010; Watterson 1975). Nucleotide diversity ranked higher for SNPs compared to other

175 approaches for the same species, as these data contain binary variable sites only (Table 2). Nucleotide

176 diversity was higher for B. pseudomallei than for Brucella spp. and Y. pestis, when SNP data were

177 analyzed. However, this was not observed for either MLST or genome data, where nucleotide diversity

178 ranked higher for Brucella spp. compared to B. pseudomallei. Y. pestis nucleotide diversity was

179 consistently lower compared to other datasets across molecular approaches. $\Theta \square$ estimates were higher 
180 for B. pseudomallei than others for SNP and genome data, but not MLST data where Brucella spp.

181 yielded the larger $\Theta$ (Table 2).

182 Rates and Ages

183 We tested whether different data approaches resulted in different inferences regarding substitution rates

184 and node ages, maintaining other parameters constant, i.e., clock calibrations, substitution models, tip

185 dates, coalescent tree priors, and taxa (different partition scheme; see Methods for details). Substitution

186 rate estimates were always higher for SNP data compared to genome data, irrespective of species

187 datasets used (Fig. 1). Rates estimated from MLST data were largely overlapping with estimates from

188 genome data for $Y$. pestis and Brucella spp. including median values (highlighted in Fig. 1B-C).

189 However, this was not the case for the B. pseudomallei dataset where, although the distributions

190 overlapped, median values for the substitution rate estimate from MLST data were higher by at least an

191 order of magnitude compared to estimates from other approaches (MLST rate median $=6.30 \mathrm{E}^{-7}$;

192 genome chr I $=6.17 \mathrm{E}^{-8}$; genome chr II $=2.48 \mathrm{E}^{-7} ; \mathrm{SNP}$ chr I $=1.06 \mathrm{E}^{-6}$; SNP chr II $=9.94 \mathrm{E}^{-7}\left[\right.$ rates $^{\text {in }}$

193 substitutions per site per year]).

194 Remarkably, when collecting node ages and comparing them across data approaches, we found 195 that highest posterior density intervals (95\% HPD) overlapped substantially in the case of $Y$. pestis and

196 Brucella spp. datasets (Fig. 2B-C). We observed the same trend with SNP and genome approaches 197 when analyzing B. pseudomallei datasets, but not with MLST data (Fig. 2A). Interestingly, in Y. pestis 198 node age estimates, we observe that 95\% HPD intervals are narrower in SNP and genome data than in 199 MLST data. This suggests that, though different molecular survey approaches result in markedly 200 different substitution rate estimates, node ages 95\% HPD are largely overlapping and thus not 201 significantly different.

202 Substitution rate estimates differ substantially (up to 2 orders of magnitude), though their 203 posterior distributions overlap to various degrees. Generally, substitution rate estimates drawn from 
204 SNP data were higher than those from MLST and genome data. However, node ages are largely

205 consistent across molecular survey approaches, especially for Brucella spp. data (interspecific and

206 intermediate diversity dataset). This supports the practice of using SNP data coupled to Bayesian

207 inference coalescent methods to infer divergence times, even though traditional reversible substitution

208 models are not specifically designed for this molecular approach. Substitution models based on models

209 for discrete morphological character changes have been suggested, but are not widely popular (Lewis 210 2001).

212 Phylogenies and Topology Comparisons

213 We wanted to determine whether different data approaches produce different phylogenies and to 214 quantify the extent of any observed differences in topology (dataset sizes in Table 2). We inferred 215 phylogenies for every species under all three molecular survey approaches, partitioned by chromosome 216 when appropriate, without assuming a molecular clock and outgroup rooted (see Methods). We used 217 two topology metrics, Matching Clusters (MC), rooted version of Matching splits (Bogdanowicz \& 218 Giaro 2012), and R-F Clusters (RC), rooted version of Robinson-Foulds metric (Bogdanowicz et al. 219 2012; Robinson \& Foulds 1981). MC distances reflect the minimal number of cluster (or clade) 220 movements needed so that the two phylogenies are topologically equivalent. RC distances measure the 221 average number of cluster differences between two phylogenies. Likewise, MC distances can be 222 interpreted as reflecting changes deep in a phylogeny, and RC distances, in turn, as reflecting changes 223 at the tip of the phylogenies or for more recent relationships. In general, we found that the phylogenies 224 inferred using MLST data are less resolved and poorly supported (posterior probabilities) than those 225 inferred by either SNP or genome data, for all species datasets (Fig. 3 and Supplemental Figure 3).

226 This is also reflected in MC distances, where topologies inferred by MLST data are as distant, or more 
so, to $\mathrm{SNP} /$ genome based topologies than between SNP and genome topologies, with some exceptions

228 (Table 3).

For Brucella spp. and Y. pestis, MC distances are clearly higher between SNP/genome and 230 MLST; however, RC distances do not follow this trend. Since MC metric concentrates more on

231 differences corresponding to branches deep in the topologies as opposed to $\mathrm{RC}$, these results suggest 232 that SNP and genome topologies have more similar backbones when compared to each other than 233 MLST topologies. Likewise, MLST topologies are more similar at the tips rather than deep in the 234 topologies (Fig. 3 and Table 3). Of course, to determine which approach is more accurate would 235 require a dataset of known evolutionary history, but SNP and genome approaches appear to be more 236 consistent with one another, especially for the deeper nodes.

Slowly evolving pathogens can be difficult to track as their populations accrue fewer substitutions, and/or genomic changes may, or may not reflect ecological processes, such as host

239 switches or geographic spread (see below for association testing). For instance, phylogenies inferred using MLST data were less resolved and poorly supported compared to their SNP and genome 241 counterparts, even though in some cases (e.g., Brucella spp. / Y. pestis) the MLST dataset size was larger than the SNP size dataset. This argues for the need to acquire genome data, as those data constitute the ultimate source of genealogical information, especially when analyzing monomorphic or 244 clonal species, i.e., Y. pestis (Achtman 2008; Achtman et al. 1999). We also found that strongly 245 supported phylogenies, e.g., those based on SNP and genome data, can support conflicting hypotheses 246 and thus will be misleading. For instance, B. pseudomallei clades, including isolates 1106a, 1106b, 247 Bp22, and BPC006, all show posterior probabilities $=1$, yet their relationships differ, hence a caveat 248 when analyzing SNP/genome data and drawing conclusions about relationships amongst isolates. 
251 Phylogenetic inference often is performed to infer ecological processes that leave a genomic imprint.

252 Phylogeny-trait associations are essential to elucidate these processes. Accordingly, we estimated the 253 Association Index (AI), and Parsimony Score (PS) on three traits (sampling location, sampling time, 254 and host), and tested whether different answers were obtained by molecular survey. Results for $B$. 255 pseudomallei showed significant association with sampling location and sampling time, but not with 256 host for most of the datasets (AI and PS; Table 4). Likewise, Y. pestis datasets were significantly 257 associated with sampling location and, to some extent, with sampling time and host. Interestingly, 258 Brucella spp. showed significant genetic structure to be associated with both sampling location and 259 host, but not sampling time (Table 4).

Irrespective of the molecular survey approach used, phylogenies derived from B. pseudomallei showed a significant association with sampling location, but not with host, suggesting similar evolutionary forces acting on $B$. pseudomallei in different hosts, or that B. pseudomallei isolates are highly endemic to the sites from which they were isolated. Similarly, Brucella spp. phylogenies were associated with both sampling location and host, irrespective of the data approach used, most likely reflecting metabolic and geographic constraints on gene flow. Interestingly, for $Y$. pestis, no significant association of host and MLST data was observed, most likely reflecting lack of signal, given the absence of resolution of phylogenies in its posterior distribution.

Molecular survey approaches do have different sets of assumptions and properties that must be considered before an analysis is done. So too, statistical models that are employed may be suited for certain data approaches and not others. Here, we used popular phylogenetic methods for all molecular approaches to test whether congruent inferences could be obtained, even though some might violate particular model assumptions. The MLST method targets housekeeping genes that are likely to be maintained across taxonomic levels, hence amenable for evolutionary inferences. Yet, similar to other 
275 not impact evolutionary inferences because of molecular convergence (Castoe et al. 2009; Edwards 276 2009) and estimation of branch lengths (Ho et al. 2011; Roje 2014). Other trade-offs of MLST have 277 been discussed elsewhere, mainly with respect to utility and how they can be refashioned in the post278 genomic era (Maiden et al. 2013; Pérez-Losada et al. 2013). On the other hand, sampling bias can 279 influence phylogenetic analysis (Lachance \& Tishkoff 2013). Here, we obtained SNP data without 280 using reference data and included globally sampled genomes and stringent quality controls (high Phred 281 scores, long k-mers) to diminish ascertainment and discovery bias (Gonçalves da Silva et al. 2014). 282 However, standard nucleotide substitution models, such as GTR, are not designed to account for binary 283 sites-only datasets nor Bayesian Inference methods, which typically factor in invariable sites, 284 influencing branch length estimation and impacting parameter estimates, such as substitution rate and 285 divergence time. Nonetheless, they have been used to date the spread of bacteria and other pathogens 286 (Comas et al. 2013; Holt et al. 2010; Holt et al. 2012; Okoro et al. 2012; Pepperell et al. 2013). We 287 speculate, based on these results, that analysis of SNP data to survey genomic variation is robust and errors in phylogenetic inference (Bertels et al. 2014).

\section{Conclusions}

The field of bacterial population genomics is advancing rapidly with larger datasets (more taxa, 293 more sites) increasingly available, including whole-genomes, making greater resolution possible and 294 more powerful exploration of complex issues (Chewapreecha et al. 2014; Nasser et al. 2014). The results of analyses reported here show that the molecular survey that is used can have a critical impact

296 on substitution rate and phylogenetic inference. However, node dates and trait associations are 297 relatively consistent irrespective of the survey tool used. We found substitution rates vary widely 298 depending on the approach taken, and SNP and genomic datasets yield different, but strongly 
supported phylogenies. Overall, inferences were more sensitive to molecular survey in the low diversity Y. pestis dataset, compared to the B. pseudomallei and Brucella spp. datasets.

Substitution rate estimates are important because, coupled to sampling dates, they allow tracking infections in space and time, and thus provide an essential epidemiological tool for monitoring and control of infectious diseases. The results presented strongly suggest that future studies should consider discordances between inferences derived from different molecular survey methods, especially with respect to substitution rate estimates.

In practice, other variables also influence what type of survey approach to use, and there are foreseeable cases where it might be practical to choose for MLST over WGS/SNPs, e.g., cost, equipment, ease of use, and necessary expertise. More importantly, coupling multiple molecular survey approaches could be useful to gain biological insights, e.g., genome evolution, gene synteny, and content using WGS; and genotyping large numbers of samples using MLSTs.

Importantly, for whole genome analysis, a subset of data is selected to run existing software to estimate population genetic parameters. Clearly, there is a need to expand the range of methods to include whole genome data analysis. However, as bacterial genomics matures, current methods will need to be modified and extended to handle the stream of data now being generated.

\section{Supplemental Information}

All supplemental information has been deposited in FigShare at http://dx.doi.org/10.6084/m9.figshare.1091392

\section{Supplemental Map: Geographic distribution of isolates used in this study}

Supplemental File 1: SRA Accession numbers for all 60 genomes contributed in this study

\section{Supplemental Figure 1: Median node ages for Burkholderia pseudomallei (A), Brucella spp. (B)}

Supplemental Figure 2: Phylogenies by molecular survey approach. Brucella spp. phylogenies (A) and Y. pestis phylogenies (B) 
325 Supplemental File 2: Datasets, Clock and non-clock phylogenies for all molecular survey approaches 326 and species

\section{Acknowledgements}

328 We would like to thank the Department of Homeland Security for funding (Grant\# HSHQDC-10-C329 00177), and the BYU Select Agent Archive for providing biological specimens. E.C.N. was funded by 330 "CONICYT + PAI/ CONCURSO NACIONAL APOYO AL RETORNO DE INVESTIGADORES/AS 331 DESDE EL EXTRANJERO, CONVOCATORIA 2014 + FOLIO 82140008". We thank the GW

332 Colonial One computing cluster for compute time for these analyses. 
335

336

337

338

339

340

341

342

343

344

345

346

347

348

349

350

351

352

353

354

355

356

357

358

359

360

361

362

363

364

365

366

367

368

369

370

371

372

373

374

375

376

377

378

379

Achtman M. 2008. Evolution, Population Structure, and Phylogeography of Genetically Monomorphic Bacterial Pathogens. Annual Review of Microbiology 62:53-70.

Achtman M, Zurth K, Morelli G, Torrea G, Guiyoule A, and Carniel E. 1999. Yersinia pestis, the cause of plague, is a recently emerged clone of Yersinia pseudotuberculosis. Proceedings of the National Academy of Sciences 96:14043-14048.

Altschul SF, Gish W, Miller W, Myers EW, and Lipman DJ. 1990. Basic local alignment search tool. Journal of molecular biology 215:403-410.

Ayres DL, Darling A, Zwickl DJ, Beerli P, Holder MT, Lewis PO, Huelsenbeck JP, Ronquist F, Swofford DL, and Cummings MP. 2012. BEAGLE: an application programming interface and high-performance computing library for statistical phylogenetics. Systematic biology 61:170173.

Baker S, Hanage WP, and Holt KE. 2010. Navigating the future of bacterial molecular epidemiology. Current opinion in microbiology 13:640-645.

Benson DA, Karsch-Mizrachi I, Lipman DJ, Ostell J, and Sayers EW. 2010. GenBank. Nucleic Acids Research 38:D46-D51.

Bertelli C, and Greub G. 2013. Rapid bacterial genome sequencing: methods and applications in clinical microbiology. Clinical Microbiology and Infection 19:803-813.

Bertels F, Silander OK, Pachkov M, Rainey PB, and van Nimwegen E. 2014. Automated Reconstruction of Whole-Genome Phylogenies from Short-Sequence Reads. Molecular Biology and Evolution 31:1077-1088.

Bogdanowicz D, and Giaro K. 2012. Matching split distance for unrooted binary phylogenetic trees. Computational Biology and Bioinformatics, IEEE/ACM Transactions on 9:150-160.

Bogdanowicz D, Giaro K, and Wróbel B. 2012. Treecmp: comparison of Trees in polynomial Time. Evolutionary Bioinformatics Online 8:475.

Bos KI, Schuenemann VJ, Golding GB, Burbano HA, Waglechner N, Coombes BK, McPhee JB, DeWitte SN, Meyer M, Schmedes S, Wood J, Earn DJD, Herring DA, Bauer P, Poinar HN, and Krause J. 2011. A draft genome of Yersinia pestis from victims of the Black Death. Nature 478:506-510.

Brinkac LM, Davidsen T, Beck E, Ganapathy A, Caler E, Dodson RJ, Durkin AS, Harkins DM, Lorenzi H, and Madupu R. 2010. Pathema: a clade-specific bioinformatics resource center for pathogen research. Nucleic Acids Research 38:D408-D414.

Butler MI, Stockwell PA, Black MA, Day RC, Lamont IL, and Poulter RTM. 2013. Pseudomonas syringae pv.actinidiae from Recent Outbreaks of Kiwi fruit Bacterial Canker Belong to Different Clones That Originated in China. PLoS ONE 8:e57464.

Castillo-Ramirez S, Corander J, Marttinen P, Aldeljawi M, Hanage W, Westh H, Boye K, Gulay Z, Bentley S, Parkhill J, Holden M, and Feil E. 2012. Phylogeographic variation in recombination rates within a global clone of methicillin-resistant Staphylococcus aureus. Genome Biology 13:R126.

Castoe TA, de Koning AJ, Kim H-M, Gu W, Noonan BP, Naylor G, Jiang ZJ, Parkinson CL, and Pollock DD. 2009. Evidence for an ancient adaptive episode of convergent molecular evolution. Proceedings of the National Academy of Sciences 106:8986-8991.

Chen C, Zhang W, Zheng H, Lan R, Wang H, Du P, Bai X, Ji S, Meng Q, Jin D, Liu K, Jing H, Ye C, Gao GF, Wang L, Gottschalk M, and Xu J. 2013. Minimum core genome sequence typing of bacterial pathogens: a unified approach for clinical and public health microbiology. Journal of Clinical Microbiology. 
Chewapreecha C, Harris SR, Croucher NJ, Turner C, Marttinen P, Cheng L, Pessia A, Aanensen DM, Mather AE, and Page AJ. 2014. Dense genomic sampling identifies highways of pneumococcal recombination. Nature genetics 46:305-309.

Comas I, Coscolla M, Luo T, Borrell S, Holt KE, Kato-Maeda M, Parkhill J, Malla B, Berg S, and Thwaites G. 2013. Out-of-Africa migration and Neolithic coexpansion of Mycobacterium tuberculosis with modern humans. Nature genetics.

Cornejo OE, Lefébure T, Pavinski Bitar PD, Lang P, Richards VP, Eilertson K, Do T, Beighton D, Zeng L, Ahn S-J, Burne RA, Siepel A, Bustamante CD, and Stanhope MJ. 2013. Evolutionary and Population Genomics of the Cavity Causing Bacteria Streptococcus mutans. Molecular Biology and Evolution 30:881-893.

Croucher NJ, Finkelstein JA, Pelton SI, Mitchell PK, Lee GM, Parkhill J, Bentley SD, Hanage WP, and Lipsitch M. 2013. Population genomics of post-vaccine changes in pneumococcal epidemiology. Nat Genet 45:656-663.

Darling AE, Mau B, and Perna NT. 2010. progressiveMauve: multiple genome alignment with gene gain, loss and rearrangement. PLoS ONE 5:e11147.

Drummond AJ, Suchard MA, Xie D, and Rambaut A. 2012. Bayesian phylogenetics with BEAUti and the BEAST 1.7. Molecular Biology and Evolution 29:1969-1973.

Edwards SV. 2009. Natural selection and phylogenetic analysis. Proceedings of the National Academy of Sciences 106:8799-8800.

Epson EE, Pisney LM, Wendt JM, MacCannell DR, Janelle SJ, Kitchel B, Rasheed JK, Limbago BM, Gould CV, and Kallen AJ. 2014. Carbapenem-Resistant Klebsiella pneumoniae Producing New Delhi Metallo- $\beta$-Lactamase at an Acute Care Hospital, Colorado, 2012. Infection Control and Hospital Epidemiology 35:390-397.

Gardner SN, and Hall BG. 2013. When Whole-Genome Alignments Just Won't Work: kSNP v2 Software for Alignment-Free SNP Discovery and Phylogenetics of Hundreds of Microbial Genomes. PLoS ONE 8:e81760.

Gardner SN, and Slezak T. 2010. Scalable SNP analyses of 100+ bacterial or viral genomes. J Forensic Res 1:107.

Gillespie JJ, Wattam AR, Cammer SA, Gabbard JL, Shukla MP, Dalay O, Driscoll T, Hix D, Mane SP, and Mao C. 2011. PATRIC: the comprehensive bacterial bioinformatics resource with a focus on human pathogenic species. Infection and immunity 79:4286-4298.

Gonçalves da Silva A, Barendse W, Kijas JW, Barris WC, McWilliam S, Bunch RJ, McCullough R, Harrison B, Hoelzel AR, and England PR. 2014. SNP discovery in nonmodel organisms: strand bias and base - substitution errors reduce conversion rates. Molecular ecology resources.

Goss EM, Tabima JF, Cooke DE, Restrepo S, Fry WE, Forbes GA, Fieland VJ, Cardenas M, and Grünwald NJ. 2014. The Irish potato famine pathogen Phytophthora infestans originated in central Mexico rather than the Andes. Proceedings of the National Academy of Sciences:201401884.

Grad YH, and Waldor MK. 2013. Deciphering the Origins and Tracking the Evolution of Cholera Epidemics with Whole-Genome-Based Molecular Epidemiology. mBio 4.

Ho SY, Lanfear R, Bromham L, Phillips MJ, Soubrier J, Rodrigo AG, and Cooper A. 2011. Time - dependent rates of molecular evolution. Molecular ecology 20:3087-3101.

Holt KE, Baker S, Dongol S, Basnyat B, Adhikari N, Thorson S, Pulickal AS, Song Y, Parkhill J, and Farrar JJ. 2010. High-throughput bacterial SNP typing identifies distinct clusters of Salmonella Typhi causing typhoid in Nepalese children. BMC infectious diseases 10:144. 
Holt KE, Baker S, Weill F-X, Holmes EC, Kitchen A, Yu J, Sangal V, Brown DJ, Coia JE, Kim DW, Choi SY, Kim SH, da Silveira WD, Pickard DJ, Farrar JJ, Parkhill J, Dougan G, and Thomson NR. 2012. Shigella sonnei genome sequencing and phylogenetic analysis indicate recent global dissemination from Europe. Nat Genet 44:1056-1059.

Hong C, Manimaran S, Shen Y, Perez-Rogers JF, Byrd AL, Castro-Nallar E, Crandall KA, and Johnson WE. 2014. PathoScope 2.0: a complete computational framework for strain identification in environmental or clinical sequencing samples. Microbiome 2:1-15.

Kearse M, Moir R, Wilson A, Stones-Havas S, Cheung M, Sturrock S, Buxton S, Cooper A, Markowitz S, and Duran C. 2012. Geneious Basic: an integrated and extendable desktop software platform for the organization and analysis of sequence data. Bioinformatics 28:16471649.

Kos VN, Desjardins CA, Griggs A, Cerqueira G, Van Tonder A, Holden MTG, Godfrey P, Palmer KL, Bodi K, Mongodin EF, Wortman J, Feldgarden M, Lawley T, Gill SR, Haas BJ, Birren B, and Gilmore MS. 2012. Comparative Genomics of Vancomycin-Resistant Staphylococcus aureus Strains and Their Positions within the Clade Most Commonly Associated with MethicillinResistant S. aureus Hospital-Acquired Infection in the United States. mBio 3.

Köser CU, Holden MTG, Ellington MJ, Cartwright EJP, Brown NM, Ogilvy-Stuart AL, Hsu LY, Chewapreecha C, Croucher NJ, Harris SR, Sanders M, Enright MC, Dougan G, Bentley SD, Parkhill J, Fraser LJ, Betley JR, Schulz-Trieglaff OB, Smith GP, and Peacock SJ. 2012. Rapid Whole-Genome Sequencing for Investigation of a Neonatal MRSA Outbreak. New England Journal of Medicine 366:2267-2275.

Lachance J, and Tishkoff SA. 2013. SNP ascertainment bias in population genetic analyses: Why it is important, and how to correct it. BioEssays.

Lemey P, Rambaut A, Bedford T, Faria N, Bielejec F, Baele G, Russell CA, Smith DJ, Pybus OG, and Brockmann D. 2014. Unifying viral genetics and human transportation data to predict the global transmission dynamics of human influenza H3N2. PLoS pathogens 10:e1003932.

Lewis PO. 2001. A likelihood approach to estimating phylogeny from discrete morphological character data. Systematic biology 50:913-925.

Lewis T, Loman NJ, Bingle L, Jumaa P, Weinstock GM, Mortiboy D, and Pallen MJ. 2010. Highthroughput whole-genome sequencing to dissect the epidemiology of Acinetobacter baumannii isolates from a hospital outbreak. Journal of Hospital Infection 75:37-41.

Li H, Handsaker B, Wysoker A, Fennell T, Ruan J, Homer N, Marth G, Abecasis G, and Durbin R. 2009. The sequence alignment/map format and SAMtools. Bioinformatics 25:2078-2079.

Li R, Li Y, Kristiansen K, and Wang J. 2008. SOAP: short oligonucleotide alignment program. Bioinformatics 24:713-714.

Liolios K, Mavromatis K, Tavernarakis N, and Kyrpides NC. 2008. The Genomes On Line Database (GOLD) in 2007: status of genomic and metagenomic projects and their associated metadata. Nucleic Acids Research 36:D475-D479.

Maiden MCJ, van Rensburg MJJ, Bray JE, Earle SG, Ford SA, Jolley KA, and McCarthy ND. 2013. MLST revisited: the gene-by-gene approach to bacterial genomics. Nat Rev Micro 11:728-736.

Markowitz VM, Chen I-MA, Palaniappan K, Chu K, Szeto E, Grechkin Y, Ratner A, Jacob B, Huang J, and Williams P. 2012. IMG: the integrated microbial genomes database and comparative analysis system. Nucleic Acids Research 40:D115-D122.

Marttinen P, Hanage WP, Croucher NJ, Connor TR, Harris SR, Bentley SD, and Corander J. 2012. Detection of recombination events in bacterial genomes from large population samples. Nucleic Acids Research 40:e6. 
Morelli G, Song Y, Mazzoni CJ, Eppinger M, Roumagnac P, Wagner DM, Feldkamp M, Kusecek B, Vogler AJ, Li Y, Cui Y, Thomson NR, Jombart T, Leblois R, Lichtner P, Rahalison L, Petersen JM, Balloux F, Keim P, Wirth T, Ravel J, Yang R, Carniel E, and Achtman M. 2010. Yersinia pestis genome sequencing identifies patterns of global phylogenetic diversity. Nat Genet 42:1140-1143.

Nasser W, Beres SB, Olsen RJ, Dean MA, Rice KA, Long SW, Kristinsson KG, Gottfredsson M, Vuopio J, and Raisanen K. 2014. Evolutionary pathway to increased virulence and epidemic group A Streptococcus disease derived from 3,615 genome sequences. Proceedings of the National Academy of Sciences:201403138.

Nei M. 1987. Molecular evolutionary genetics: Columbia University Press.

Okoro CK, Kingsley RA, Connor TR, Harris SR, Parry CM, Al-Mashhadani MN, Kariuki S, Msefula CL, Gordon MA, de Pinna E, Wain J, Heyderman RS, Obaro S, Alonso PL, Mandomando I, MacLennan CA, Tapia MD, Levine MM, Tennant SM, Parkhill J, and Dougan G. 2012. Intracontinental spread of human invasive Salmonella Typhimurium pathovariants in subSaharan Africa. Nat Genet 44:1215-1221.

Paradis E. 2010. pegas: an R package for population genetics with an integrated-modular approach. Bioinformatics 26:419-420.

Paradis E, Claude J, and Strimmer K. 2004. APE: analyses of phylogenetics and evolution in R language. Bioinformatics 20:289-290.

Parker J, Rambaut A, and Pybus OG. 2008. Correlating viral phenotypes with phylogeny: accounting for phylogenetic uncertainty. Infection, Genetics and Evolution 8:239-246.

Pepperell CS, Casto AM, Kitchen A, Granka JM, Cornejo OE, Holmes EC, Birren B, Galagan J, and Feldman MW. 2013. The Role of Selection in Shaping Diversity of Natural M. tuberculosis Populations. PLoS pathogens 9:e1003543.

Pérez-Lago L, Comas I, Navarro Y, González-Candelas F, Herranz M, Bouza E, and García-deViedma D. 2013. Whole Genome Sequencing analysis of intrapatient microevolution in Mycobacterium tuberculosis: Potential impact on the inference of tuberculosis transmission. Journal of Infectious Diseases 209:98-108.

Pérez-Losada M, Cabezas P, Castro-Nallar E, and Crandall KA. 2013. Pathogen typing in the genomics era: MLST and the future of molecular epidemiology. Infection, Genetics and Evolution 16:3853.

Pettengill JB, Luo Y, Davis S, Chen Y, Gonzalez-Escalona N, Ottesen A, Rand H, Allard MW, and Strain E. 2014. An evaluation of alternative methods for constructing phylogenies from whole genome sequence data: a case study with Salmonella. PeerJ 2:e620.

Raphael BH, Shirey TB, Lúquez C, and Maslanka SE. 2014. Distinguishing highly-related outbreakassociated Clostridium botulinum type A (B) strains. BMC Microbiology 14:192.

Read TD, Salzberg SL, Pop M, Shumway M, Umayam L, Jiang L, Holtzapple E, Busch JD, Smith KL, and Schupp JM. 2002. Comparative genome sequencing for discovery of novel polymorphisms in Bacillus anthracis. Science 296:2028-2033.

Reimer AR, Van Domselaar G, Stroika S, Walker M, Kent H, Tarr C, Talkington D, Rowe L, OlsenRasmussen M, Frace M, Sammons S, Dahourou GA, Boncy J, Smith AM, Mabon P, Petkau A, Graham M, Gilmour MW, and Gerner-Smidt P. 2011. Comparative genomics of Vibrio cholerae from Haiti, Asia, and Africa. Emerg Infect Dis 17:2113-2121.

Revazishvili T, Rajanna C, Bakanidze L, Tsertsvadze N, Imnadze P, O’Connell K, Kreger A, Stine O, Morris J, and Sulakvelidze A. 2008. Characterisation of Yersinia pestis isolates from natural foci of plague in the Republic of Georgia, and their relationship to Y. pestis isolates from other countries. Clinical Microbiology and Infection 14:429-436. 
518 Robinson D, and Foulds LR. 1981. Comparison of phylogenetic trees. Mathematical Biosciences $519 \quad 53: 131-147$.

Roje DM. 2014. Evaluating the Effects of Non-Neutral Molecular Markers on Phylogeny Inference. PLoS ONE 9:e87428.

Ronquist F, Teslenko M, van der Mark P, Ayres DL, Darling A, Höhna S, Larget B, Liu L, Suchard MA, and Huelsenbeck JP. 2012. MrBayes 3.2: efficient Bayesian phylogenetic inference and model choice across a large model space. Systematic biology 61:539-542.

Sheppard SK, Didelot X, Meric G, Torralbo A, Jolley KA, Kelly DJ, Bentley SD, Maiden MCJ, Parkhill J, and Falush D. 2013. Genome-wide association study identifies vitamin B5 biosynthesis as a host specificity factor in Campylobacter. Proceedings of the National Academy of Sciences 110:11923-11927.

Slatkin M, and Maddison WP. 1989. A cladistic measure of gene flow inferred from the phylogenies of alleles. Genetics 123:603-613.

Snow G, and Snow MG. 2013. Package 'TeachingDemos'.

Spoor LE, McAdam PR, Weinert LA, Rambaut A, Hasman H, Aarestrup FM, Kearns AM, Larsen AR, Skov RL, and Fitzgerald JR. 2013. Livestock Origin for a Human Pandemic Clone of Community-Associated Methicillin-Resistant Staphylococcus aureus. mBio 4.

Timme RE, Pettengill JB, Allard MW, Strain E, Barrangou R, Wehnes C, Van Kessel JS, Karns JS, Musser SM, and Brown EW. 2013. Phylogenetic diversity of the enteric pathogen Salmonella enterica subsp. enterica inferred from genome-wide reference-free SNP characters. Genome biology and evolution 5:2109-2123.

Wang T, Donaldson Y, Brettle R, Bell J, and Simmonds P. 2001. Identification of shared populations of human immunodeficiency virus type 1 infecting microglia and tissue macrophages outside the central nervous system. Journal of virology 75:11686-11699.

Warinner C, Rodrigues JFM, Vyas R, Trachsel C, Shved N, Grossmann J, Radini A, Hancock Y, Tito RY, and Fiddyment S. 2014. Pathogens and host immunity in the ancient human oral cavity. Nature genetics 46:336-344.

Watterson G. 1975. On the number of segregating sites in genetical models without recombination. Theoretical population biology 7:256-276.

Whatmore A, Perrett L, and MacMillan A. 2007. Characterisation of the genetic diversity of Brucella by multilocus sequencing. BMC Microbiology 7:34.

Wickham H. 2009. ggplot2: elegant graphics for data analysis: Springer Publishing Company, Incorporated.

Wielgoss S, Barrick JE, Tenaillon O, Wiser MJ, Dittmar WJ, Cruveiller S, Chane-Woon-Ming B, Médigue C, Lenski RE, and Schneider D. 2013. Mutation rate dynamics in a bacterial population reflect tension between adaptation and genetic load. Proceedings of the National Academy of Sciences 110:222-227.

Wilson MR, Allard MW, and Brown EW. 2013. The forensic analysis of foodborne bacterial pathogens in the age of whole-genome sequencing. Cladistics 29:449-461.

Zhang Z, Chen D, Chen Y, Liu W, Wang L, Zhao F, and Yao B. 2010. Spatio-Temporal Data Comparisons for Global Highly Pathogenic Avian Influenza (HPAI) H5N1 Outbreaks. PLoS ONE 5:e15314. 


\section{1}

Substitution rates for all datasets as estimated from different molecular survey approaches

Genome/SNP chr 1/II refers to estimates from different chromosomes. Burkholderia pseudomallei (A), Brucella spp. (B), and Yersinia pestis (C). Note different scale for species rates
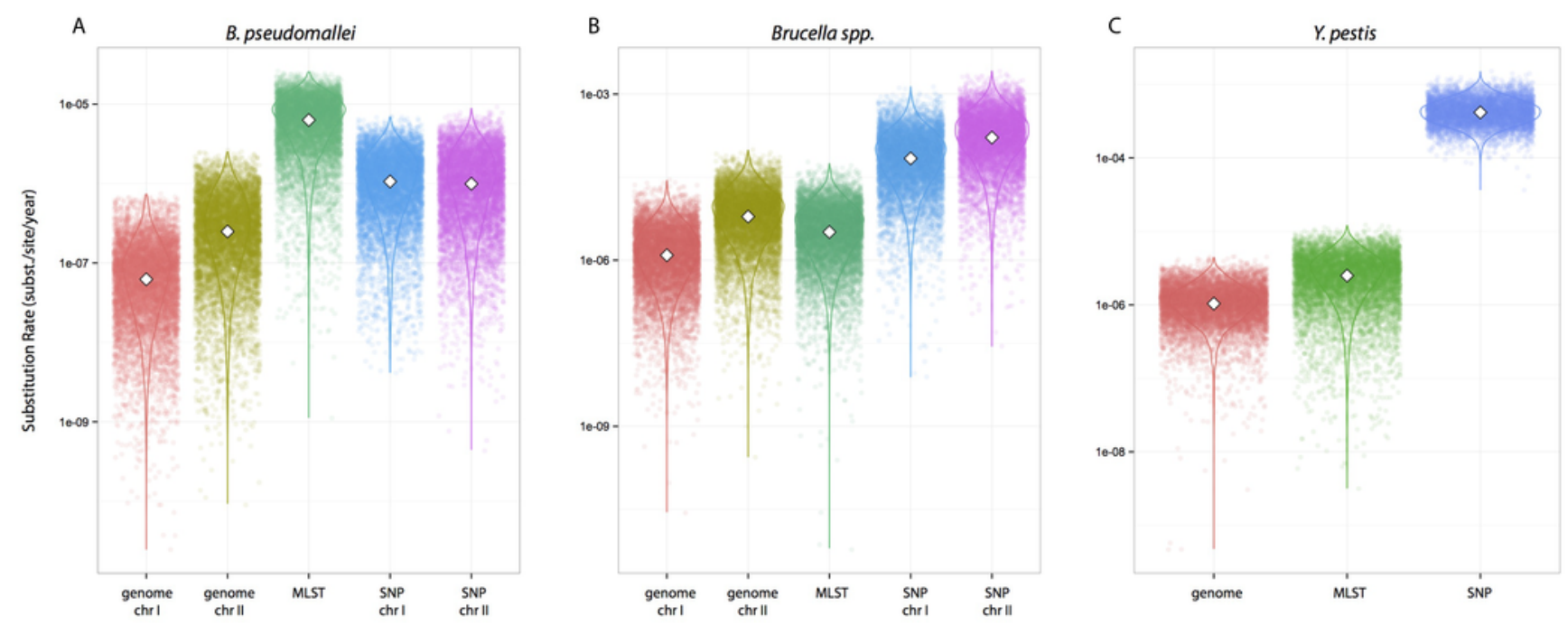
2

Median node ages in years

Burkholderia pseudomallei (A), Brucella spp. (B), and Yersinia pestis (C) median estimates and their $95 \%$ highest posterior density (HPD) interval according to molecular survey approach (only chromosome I showed; see Supplemental Figure 1). Nodes are numbered from youngest to oldest 
A

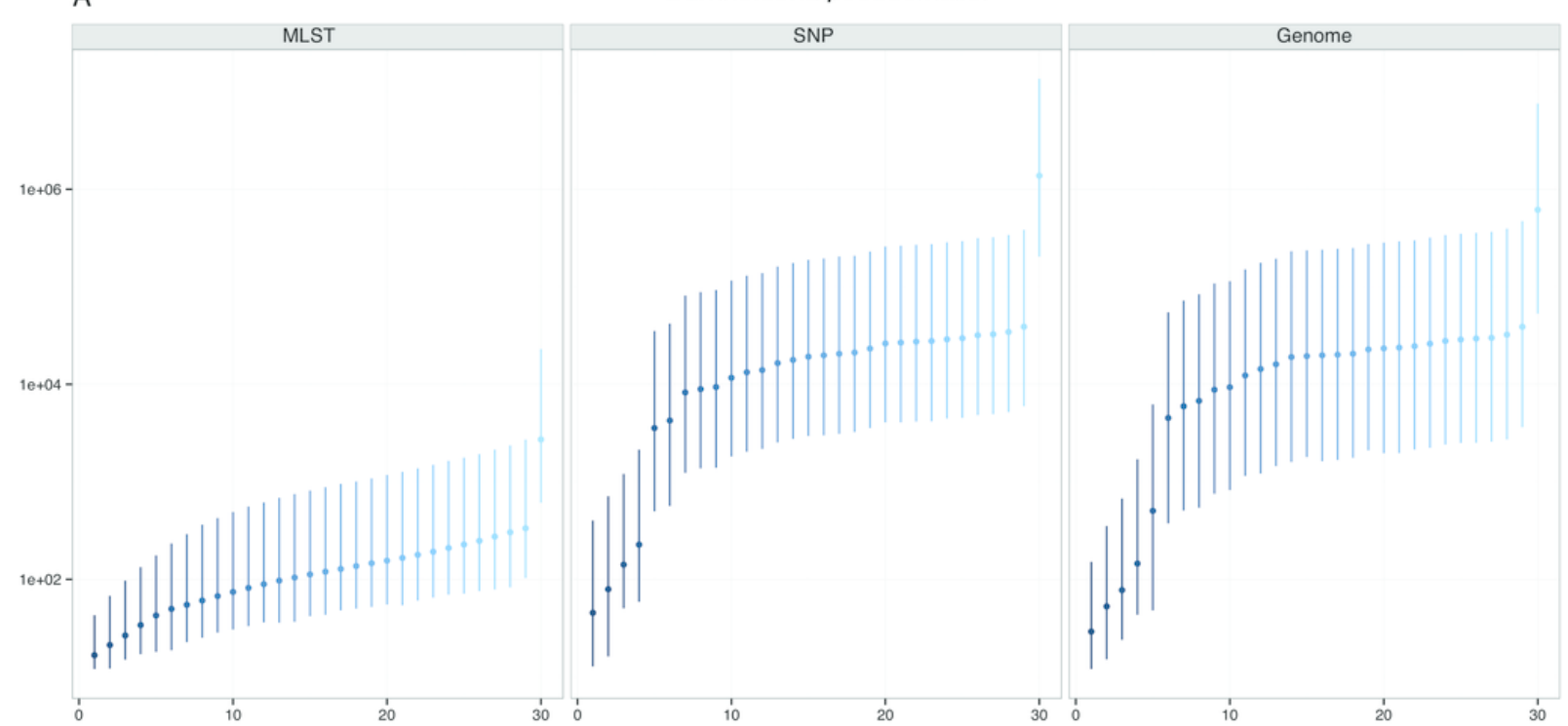

B

Brucella spp.

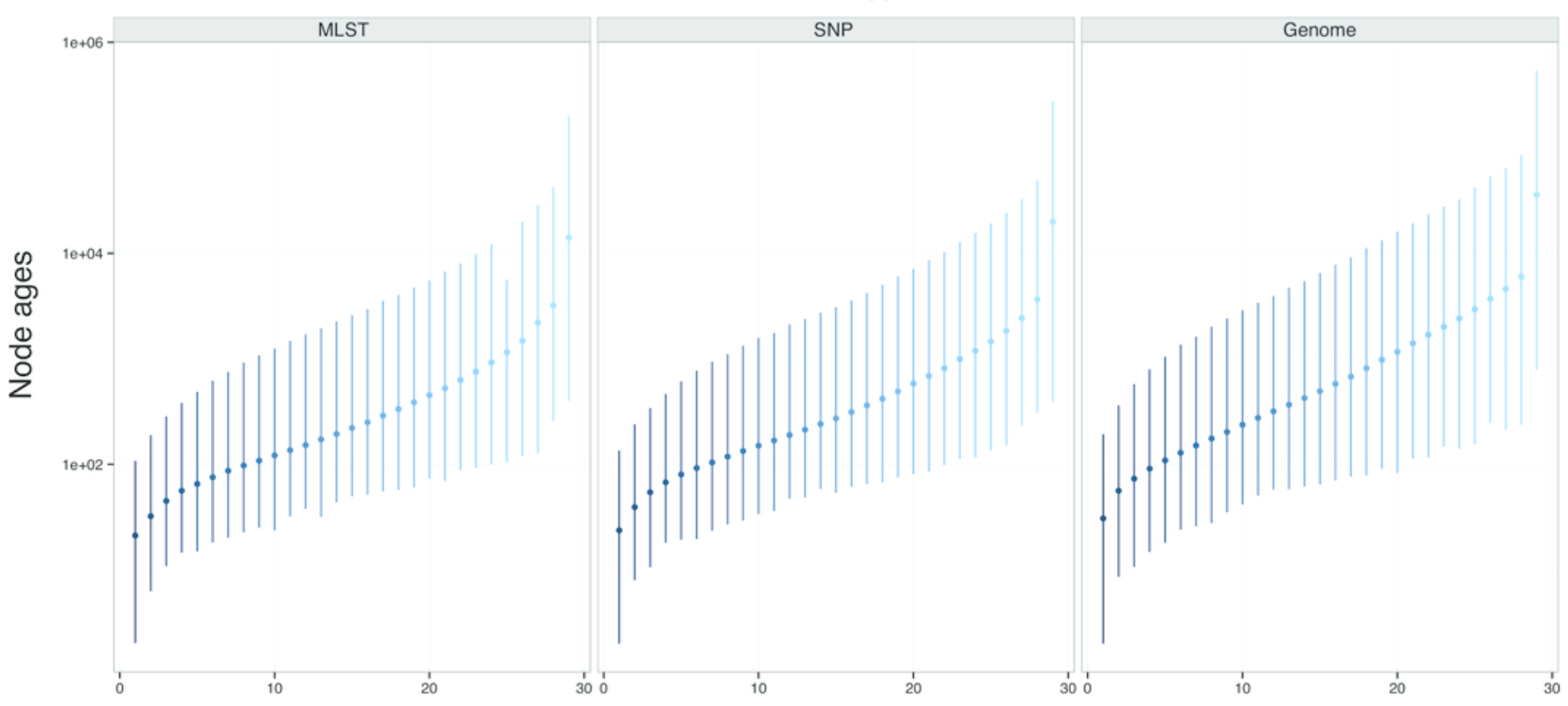

$$
\text { C }
$$

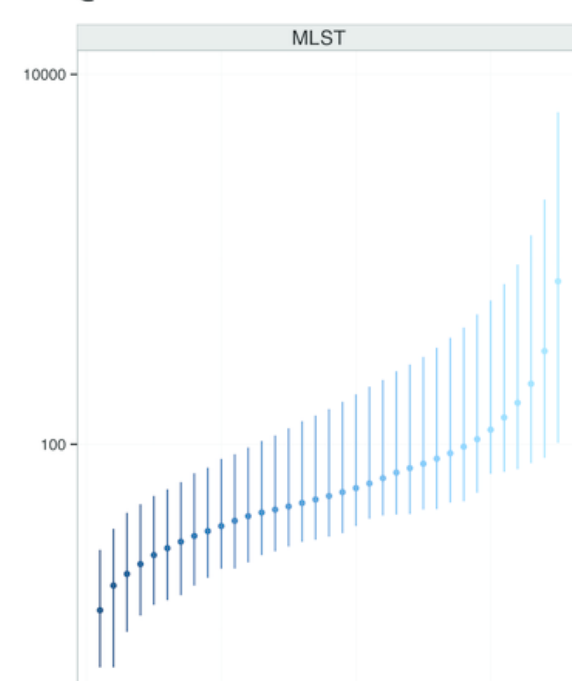

PeerJ reviewing PDF |'(v2014:09:2782:1:1:NEW 15 Jan 2015) ${ }^{20}$

Yersinia pestis

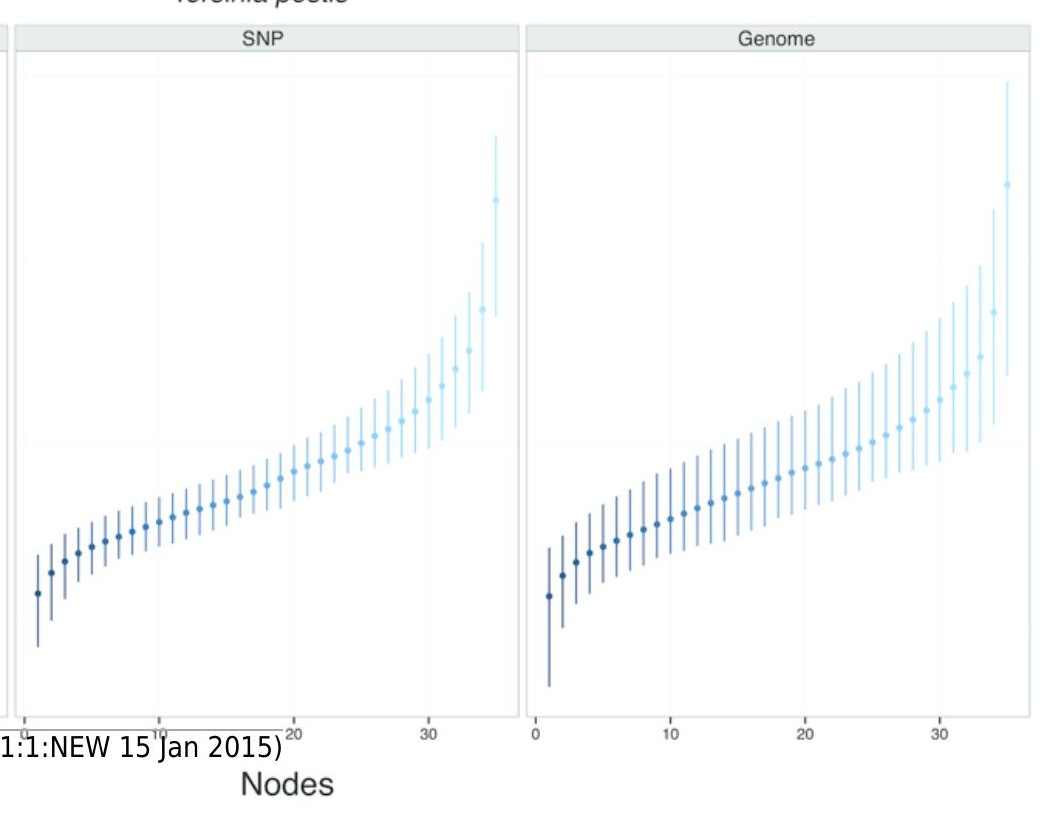


3

Burkholderia pseudomallei phylogenies by survey approach

MLST phylogeny (A) is less resolved and poorly supported compared to SNP (B) and genome (C) phylogenies (only chromosome I showed)

A

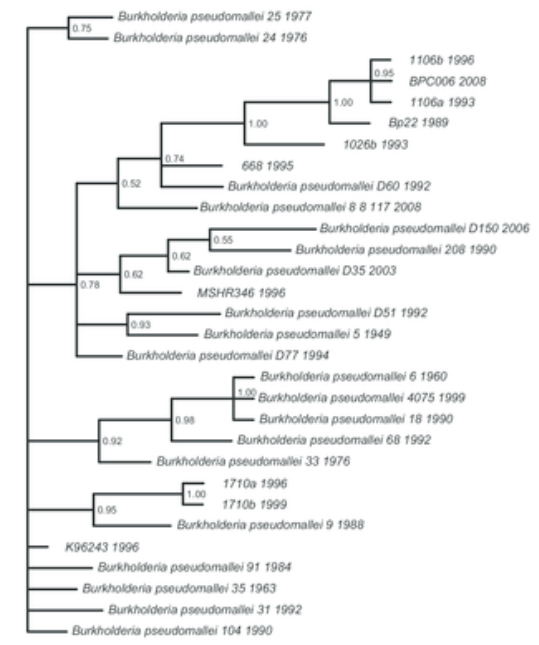

B

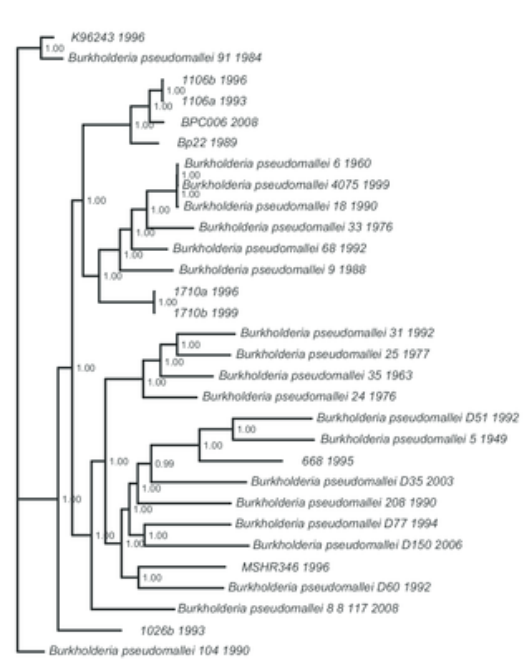

C Genome

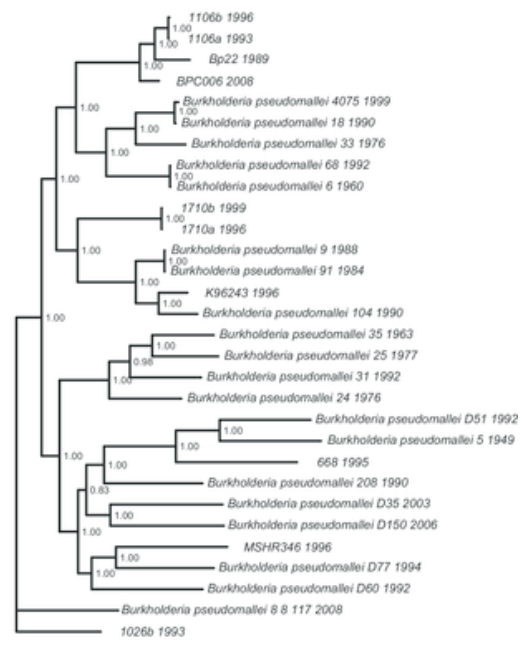




\section{Table $\mathbf{1}$ (on next page)}

Summary of genomes sequenced and collected in this study

Metadata on strain source, host, location and date of collection also provided when available 
NCBI

Accession

Species

Strain

Source

Host

Location

Date of Number

SRX286342

Burkholderia

Public Health Laboratory pseudomallei

Service, London

$\begin{array}{lll}\text { Sheep } & \text { Australia } & 1949\end{array}$

Public Health Laboratory

Burkholderia

6

Service, London

Human Bangladesh

1960

Public Health Laboratory

Burkholderia

SRX286346

pseudomallei

9

Service, London

Human Pakistan

1988

Public Health Laboratory

SRX286345

Burkholderia

Burkholderia

SRX286357

pseudomallei

Service, London

Monkey Indonesia

1990

Public Health Laboratory

Service, London

Horse France

1976

Public Health Laboratory

SRX286354

Burkholderia

pseudomallei

Service, London

Soil $\quad$ Madagascar $\quad 1977$

Public Health Laboratory

Water

Burkholderia

SRX286353

pseudomallei

Service, London

Drain

Kenya

1992

Public Health Laboratory

Manure France

1976

Public Health Laboratory

SRX286350

Burkholderia

Service, London

Human Vietnam

1963

Public Health Laboratory

SRX286348

Burkholderia pseudomallei

Service, London

Human

Fiji

1992

SRX286359

pseudomallei

Public Health Laboratory

Service, London

Sheep Australia

1984

Public Health Laboratory

SRX286361

Burkholderia

pseudomallei

Service, London

Goat Australia

1990 


\begin{tabular}{|c|c|c|c|c|c|c|}
\hline SRX286363 & $\begin{array}{l}\text { Burkholderia } \\
\text { pseudomallei }\end{array}$ & 208 & $\begin{array}{l}\text { Public Health Laboratory } \\
\text { Service, London }\end{array}$ & Human & Ecuador & 1990 \\
\hline SRX286364 & $\begin{array}{l}\text { Burkholderia } \\
\text { pseudomallei }\end{array}$ & 4075 & $\begin{array}{l}\text { Public Health Laboratory } \\
\text { Service, London }\end{array}$ & Human & Holland & 1999 \\
\hline SRX286418 & $\begin{array}{l}\text { Burkholderia } \\
\text { pseudomallei }\end{array}$ & Darwin-035 & Royal Darwin Hospital & Human & Australia & 2003 \\
\hline SRX286420 & $\begin{array}{l}\text { Burkholderia } \\
\text { pseudomallei }\end{array}$ & Darwin-051 & Royal Darwin Hospital & Dog & Australia & 1992 \\
\hline SRX286421 & $\begin{array}{l}\text { Burkholderia } \\
\text { pseudomallei }\end{array}$ & Darwin-060 & Royal Darwin Hospital & Pig & Australia & 1992 \\
\hline SRX286422 & $\begin{array}{l}\text { Burkholderia } \\
\text { pseudomallei } \\
\text { Burkholderia }\end{array}$ & Darwin-077 & Royal Darwin Hospital & Bird & Australia & 1994 \\
\hline SRX286423 & pseudomallei & Darwin-150 & Royal Darwin Hospital & Soil & Australia & 2006 \\
\hline SRX286344 & $\begin{array}{l}\text { Burkholderia } \\
\text { pseudomallei }\end{array}$ & 80800117 & $\begin{array}{l}\text { Utah Department of } \\
\text { Health }\end{array}$ & Human & USA & 2008 \\
\hline $\begin{array}{l}\text { NC_017832.1 } \\
\text { NC_017831.1 }\end{array}$ & $\begin{array}{l}\text { Burkholderia } \\
\text { pseudomallei }\end{array}$ & 1026b & $\begin{array}{l}\text { hhayden@u.washington.e } \\
\text { du }\end{array}$ & Human & Thailand & 1993 \\
\hline NC_009078.1 & Burkholderia & & & & & \\
\hline NC_009076.1 & pseudomallei & 1106a & JCVI & Human & Thailand & 1993 \\
\hline NC_012695.1 & $\begin{array}{l}\text { Burkholderia } \\
\text { pseudomallei }\end{array}$ & MSHR346 & LANL DOE JGI & Human & Australia & 1996 \\
\hline $\begin{array}{l}\text { NC_006351.1 } \\
\text { NC_006350.1 }\end{array}$ & $\begin{array}{l}\text { Burkholderia } \\
\text { pseudomallei }\end{array}$ & k96243 & Sanger Institute & Human & Thailand & 1996 \\
\hline $\begin{array}{l}\text { NC_018529.1 } \\
\text { NC_018527.1 } \\
\text { NZ_CM000774. } \\
1\end{array}$ & $\begin{array}{l}\text { Burkholderia } \\
\text { pseudomallei }\end{array}$ & BPC006 & $\begin{array}{l}\text { Third military technical } \\
\text { university }\end{array}$ & Human & China & 2008 \\
\hline${ }_{1}^{N Z}{ }_{-}$CM000775. & $\begin{array}{l}\text { Burkholderia } \\
\text { pseudomallei }\end{array}$ & 1106b & JCVI & Human & Thailand & 1996 \\
\hline
\end{tabular}




\begin{tabular}{|c|c|c|c|c|c|c|}
\hline${ }_{1}^{N Z}{ }_{-}$ & $\begin{array}{l}\text { Burkholderia } \\
\text { pseudomallei }\end{array}$ & $1710 a$ & $\mathrm{JCVI}$ & Human & Thailand & 1996 \\
\hline $\begin{array}{l}\text { NC_007435.1 } \\
\text { NC_007434.1 }\end{array}$ & $\begin{array}{l}\text { Burkholderia } \\
\text { pseudomallei }\end{array}$ & $1710 \mathrm{~b}$ & JCVI & Human & Thailand & 1999 \\
\hline $\begin{array}{l}\text { NC_009074.1 } \\
\text { NC_009075.1 } \\
\text { NZ_CM001156. } \\
1 \\
\text { NZ CM001157. }\end{array}$ & $\begin{array}{l}\text { Burkholderia } \\
\text { pseudomallei }\end{array}$ & 668 & JCVI & Human & Australia & 1995 \\
\hline 1 - & pseudomallei & Bp22 & GIS & Human & Singapore & 1989 \\
\hline $\begin{array}{l}\text { NC_007651 } \\
\text { NC_007650 }\end{array}$ & $\begin{array}{l}\text { Burkholderia } \\
\text { thailandensis }\end{array}$ & E264 & JCVI & soil & Thailand & 1994 \\
\hline SRX278648 & Brucella abortus & $\begin{array}{l}\text { 1004, Strain } \\
2032\end{array}$ & $\begin{array}{l}\text { National Animal Disease } \\
\text { Center }\end{array}$ & Bovine & MO, USA & 1990 \\
\hline SRX278790 & Brucella abortus & $\begin{array}{l}1007, \text { Strain } \\
2045\end{array}$ & $\begin{array}{l}\text { National Animal Disease } \\
\text { Center }\end{array}$ & Bovine & FL, USA & 1990 \\
\hline SRX278791 & Brucella abortus & $\begin{array}{l}\text { 1019, Strain } \\
2038\end{array}$ & $\begin{array}{l}\text { National Animal Disease } \\
\text { Center }\end{array}$ & Bovine & TN, USA & 1990 \\
\hline SRX278792 & Brucella abortus & $\begin{array}{l}\text { 1022, Strain } \\
2073\end{array}$ & $\begin{array}{l}\text { National Animal Disease } \\
\text { Center }\end{array}$ & Bovine & GA, USA & 1990 \\
\hline SRX278793 & Brucella abortus & $\begin{array}{l}\text { 1146, Strain } \\
8-953\end{array}$ & $\begin{array}{l}\text { National Animal Disease } \\
\text { Center }\end{array}$ & Elk & MT, USA & 1992 \\
\hline SRX278794 & Brucella abortus & $\begin{array}{l}\text { 1668, Strain } \\
00-666\end{array}$ & $\begin{array}{l}\text { National Animal Disease } \\
\text { Center }\end{array}$ & $\begin{array}{l}\text { Elk } \\
\text { Bison } \\
\text { (amnintic }\end{array}$ & WY, USA & 2000 \\
\hline SRX278891 & Brucella abortus & YELL-99-067 & INEEL & fluid) & WY, USA & 1999 \\
\hline SRX282032 & Brucella abortus & $\begin{array}{l}\text { 1614, Strain } \\
\text { Weinheimer }\end{array}$ & $\begin{array}{l}\text { National Animal Disease } \\
\text { Center }\end{array}$ & Bovine & TX, USA & 2000 \\
\hline
\end{tabular}




\begin{tabular}{|c|c|c|c|c|c|c|}
\hline SRX282039 & Brucella canis & $\begin{array}{l}\text { 1107, Strain } \\
1-107\end{array}$ & $\begin{array}{l}\text { National Animal Disease } \\
\text { Center }\end{array}$ & Canine & MO, USA & 1990 \\
\hline SRX282040 & $\begin{array}{l}\text { Brucella } \\
\text { melitensis }\end{array}$ & $\begin{array}{l}\text { 1253, Strain } \\
\text { Ether, L657 }\end{array}$ & $\begin{array}{l}\text { National Animal Disease } \\
\text { Center }\end{array}$ & Caprine & unknown & 1994 \\
\hline SRX282041 & $\begin{array}{l}\text { Brucella } \\
\text { melitensis }\end{array}$ & BA 4837 & $\begin{array}{l}\text { New Mexico Department } \\
\text { of Health }\end{array}$ & human & NM, USA & 2003 \\
\hline SRX282042 & $\begin{array}{l}\text { Brucella } \\
\text { melitensis }\end{array}$ & 70000565 & $\begin{array}{l}\text { Utah Department of } \\
\text { Health }\end{array}$ & $\begin{array}{l}\text { blood, } \\
\text { human }\end{array}$ & UT, USA & 2000 \\
\hline SRX282044 & $\begin{array}{l}\text { Brucella } \\
\text { melitensis }\end{array}$ & 80600020 & $\begin{array}{l}\text { Utah Department of } \\
\text { Health }\end{array}$ & $\begin{array}{l}\text { blood, } \\
\text { human }\end{array}$ & UT, USA & 2006 \\
\hline SRX282045 & $\begin{array}{l}\text { Brucella } \\
\text { melitensis }\end{array}$ & $\begin{array}{l}80800076 \\
1156, \text { Strain }\end{array}$ & $\begin{array}{l}\text { Utah Department of } \\
\text { Health }\end{array}$ & human & CA, USA & 2008 \\
\hline SRX282046 & Brucella neotomae & $\begin{array}{l}5 \mathrm{~K} 33 \\
\text { ATCC\#23459 }\end{array}$ & $\begin{array}{l}\text { National Animal Disease } \\
\text { Center }\end{array}$ & $\begin{array}{l}\text { desert wood } \\
\text { rat }\end{array}$ & $\begin{array}{l}\text { unknown, } \\
\text { USA }\end{array}$ & 1992 \\
\hline SRX282047 & Brucella ovis & $\begin{array}{l}\text { 1117, Strain } \\
1-507 \\
1698, \text { Strain }\end{array}$ & $\begin{array}{l}\text { National Animal Disease } \\
\text { Center }\end{array}$ & Ovine & GA, USA & 1991 \\
\hline SRX282048 & Brucella ovis & $\begin{array}{l}\text { 13551-2114; } \\
\text { 1985:Dhyatt }\end{array}$ & $\begin{array}{l}\text { National Animal Disease } \\
\text { Center }\end{array}$ & $\begin{array}{l}\text { Ovine } \\
\text { (semen) }\end{array}$ & $\begin{array}{l}\text { Ft. Collins, } \\
\text { CO, USA }\end{array}$ & 2001 \\
\hline SRX282050 & Brucella species & 70100304 & $\begin{array}{l}\text { Utah Department of } \\
\text { Health }\end{array}$ & $\begin{array}{l}\text { blood, } \\
\text { human }\end{array}$ & USA- UT & 2001 \\
\hline SRX282053 & Brucella suis & $\begin{array}{l}1103, \text { Strain } \\
2483\end{array}$ & $\begin{array}{l}\text { National Animal Disease } \\
\text { Center }\end{array}$ & Porcine & SC, USA & 1990 \\
\hline SRX282057 & Brucella suis & $\begin{array}{l}1108, \text { Strain } \\
1-138\end{array}$ & $\begin{array}{l}\text { National Animal Disease } \\
\text { Center }\end{array}$ & Porcine & NJ, USA & 1990 \\
\hline $\begin{array}{l}\text { NC_016777.1 } \\
\text { NC_016795.1 }\end{array}$ & Brucella abortus & A13334 & Macrogen & bovine & Korea & known \\
\hline
\end{tabular}




\begin{tabular}{|c|c|c|c|c|c|c|}
\hline $\begin{array}{l}\text { NC_006932.1 } \\
\text { NC_006933.1 }\end{array}$ & Brucella abortus & bv 1, 9-941 & USDA & bovine & WY, USA & unknown \\
\hline NC_010740.1 & & & & & unknown, & \\
\hline $\begin{array}{l}\text { NC_010742.1 } \\
\text { NC_010103.1 }\end{array}$ & Brucella abortus & S19 & Crasta OR & bovine & USA & 1923 \\
\hline NC_010104.1 & Brucella canis & ATCC 23365 & DOE JGI & Dog & unknown & unknown \\
\hline $\begin{array}{l}\text { NC_016796.1 } \\
\text { NC_016778.1 }\end{array}$ & Brucella canis & HSK A52141 & $\begin{array}{l}\text { National Veterinary } \\
\text { Research and Quarantine }\end{array}$ & dog & $\begin{array}{l}\text { South } \\
\text { Korea }\end{array}$ & unknown \\
\hline $\begin{array}{l}\text { NC_012442.1 } \\
\text { NC_012441.1 }\end{array}$ & $\begin{array}{l}\text { Brucella } \\
\text { melitensis }\end{array}$ & ATCC 23457 & $\begin{array}{l}\text { LANL } \\
\text { Chinese National Human }\end{array}$ & human & India & 1963 \\
\hline $\begin{array}{l}\text { NC_017244.1 } \\
\text { NC_017245.1 }\end{array}$ & $\begin{array}{l}\text { Brucella } \\
\text { melitensis }\end{array}$ & M28 & $\begin{array}{l}\text { Genome Center at } \\
\text { Shanghai }\end{array}$ & sheep & China & 1955 \\
\hline $\begin{array}{l}\text { NC_003317.1 } \\
\text { NC_003318.1 }\end{array}$ & $\begin{array}{l}\text { Brucella } \\
\text { melitensis }\end{array}$ & $\begin{array}{l}\text { bv } 1,16 \mathrm{M} \\
\text { bv. } 1\end{array}$ & Integrated Genomics Inc & $\begin{array}{l}\text { goat } \\
\text { Standard }\end{array}$ & $\begin{array}{l}\text { unknown, } \\
\text { USA }\end{array}$ & unknown \\
\hline NC_007618.1 & Brucella & Abortus & Lawrence Livermore & laboratory & & \\
\hline NC_007624.1 & melitensis & 2308 & $\begin{array}{l}\text { National Lab } \\
\text { Chinese National Human }\end{array}$ & $\begin{array}{l}\text { strain } \\
\text { Standard }\end{array}$ & unknown & unknown \\
\hline $\begin{array}{l}\text { NC_017246.1 } \\
\text { NC_017247.1 }\end{array}$ & $\begin{array}{l}\text { Brucella } \\
\text { melitensis }\end{array}$ & M5-90 & $\begin{array}{l}\text { Genome Center at } \\
\text { Shanghai }\end{array}$ & $\begin{array}{l}\text { laboratory } \\
\text { strain }\end{array}$ & $\begin{array}{l}\text { unknown } \\
\text { Inner }\end{array}$ & unknown \\
\hline $\begin{array}{l}\text { NC_017248.1 } \\
\text { NC_017283.1 } \\
\text { CP-001578.1 }\end{array}$ & $\begin{array}{l}\text { Brucella } \\
\text { melitensis }\end{array}$ & bv. $3 \mathrm{NI}$ & China Agricultural Univ & bovine & $\begin{array}{l}\text { Mongolia, } \\
\text { China } \\
\text { Czech }\end{array}$ & 2007 \\
\hline $\begin{array}{l}\text { CP001579.1 } \\
\text { NC_009505.1 }\end{array}$ & Brucella microti & CCM 4915 & Sudic S & vole & Republic & 2000 \\
\hline NC_009504.1 & Brucella ovis & ATCC 25840 & J. Craig Venter Institute & sheep & Australia & 1960 \\
\hline $\begin{array}{l}\text { NC_015858.1 } \\
\text { NC_015857.1 } \\
\text { NC_016775.1 } \\
\text { NC_016797.1 }\end{array}$ & $\begin{array}{l}\text { Brucella } \\
\text { pinnipedialis } \\
\text { Brucella suis }\end{array}$ & VBI22 & $\begin{array}{l}\text { Zygmunt,M.S. } \\
\text { Harold R. Garner }\end{array}$ & $\begin{array}{l}\text { seal } \\
\text { Bovine, } \\
\text { milk }\end{array}$ & TX, USA & $\begin{array}{r}1994 \\
\text { unknown }\end{array}$ \\
\hline
\end{tabular}


NC_004311.2

NC_004310.3

NC_010167.1

NC_010169.1

Brucella suis

Brucella suis

bv 1, 1330

J. Craig Venter Institute

ATCC 23445 LANL DOE JGI

NC_009667.1

NC_009668.1

Ochrobactrum

anthropi

SRX282065

Yersinia pestis

SRX282089

SRX282090

Yersinia pestis

Yersinia pestis

SRX282091

Yersinia pestis

SRX282092

SRX282093

Yersinia pestis

Yersinia pestis

SRX282094

Yersinia pestis

SRX282095

Yersinia pestis

SRX282096

SRX286281

SRX286283

SRX286290
Yersina pestis

Yersinia pestis

Yersinia pestis

Yersinia pestis
ATCC

49188

4954

$1901 b$

Java (D88)

Kimberley

(D17)

KUMA (D11)

TS (D5)

8607116

1866

4139

4412

2965

2055
DOE JGI

New Mexico Department of Health

New Mexico Department of Health

Michigan State University

Michigan State University

Michigan State University

Michigan State University

New Mexico Department of Health

New Mexico Department of Health

New Mexico Department of Health

New Mexico Department of Health

New Mexico Department of Health

New Mexico Department of Health unknown,

USA

1950

hare

UK

Arsenical

cattle-

dipping

fluid

Australia

1988

Human

NM, USA

1987

Human

NM, USA

1983

unknown

Far East

unknown

unknown

Near East

Manchuria,

unknown

China

unknown

Far East

Dog

NM, USA

unknown

Squirrel

NM, USA

unknown

cat

NM, USA

1995

Human NM, USA

1991

Human NM, USA

1995

Human NM, USA 


\begin{tabular}{|c|c|c|c|c|c|c|}
\hline SRX286302 & Yersinia pestis & 2106 & $\begin{array}{l}\text { New Mexico Department } \\
\text { of Health }\end{array}$ & Human & NM, USA & 2001 \\
\hline SRX286303 & Yersinia pestis & 2772 & $\begin{array}{l}\text { New Mexico Department } \\
\text { of Health }\end{array}$ & Cat & NM, USA & 1984 \\
\hline SRX286304 & Yersinia pestis & 3357 & $\begin{array}{l}\text { New Mexico Department } \\
\text { of Health }\end{array}$ & $\begin{array}{l}\text { mountain } \\
\text { lion }\end{array}$ & NM, USA & 1999 \\
\hline SRX286305 & Yersinia pestis & AS 2509 & $\begin{array}{l}\text { New Mexico Department } \\
\text { of Health }\end{array}$ & Rodent & $\begin{array}{l}\text { NM, USA } \\
\text { United }\end{array}$ & 2004 \\
\hline SRX286306 & Yersinia pestis & $\begin{array}{l}\text { AS } \\
200900596\end{array}$ & $\begin{array}{l}\text { New Mexico Department } \\
\text { of Health }\end{array}$ & $\begin{array}{l}\text { rabbit, } \\
\text { liver/spleen }\end{array}$ & $\begin{array}{l}\text { States, } \\
\text { Santa Fe, } \\
\text { NM }\end{array}$ & 2009 \\
\hline SRX286307 & Yersinia pestis & V-6486 & $\begin{array}{l}\text { New Mexico Department } \\
\text { of Health }\end{array}$ & Llama & $\begin{array}{l}\text { Las Vegas, } \\
\text { NM, USA }\end{array}$ & unknown \\
\hline SRX286340 & Yersinia pestis & KIM (D27) & Michigan State University & Human & $\begin{array}{l}\text { Iran/Kurdista } \\
\mathrm{n}\end{array}$ & 1968 \\
\hline SRX286341 & Yersinia pestis & $\begin{array}{l}\text { AS20090150 } \\
9\end{array}$ & $\begin{array}{l}\text { New Mexico Department } \\
\text { of Health }\end{array}$ & $\begin{array}{l}\text { liver/spleen } \\
\text {, prairie } \\
\text { dog }\end{array}$ & $\begin{array}{l}\text { Santa Fe, } \\
\text { NM, USA }\end{array}$ & 2009 \\
\hline NC_017168.1 & Yersinia pestis & A1122 & 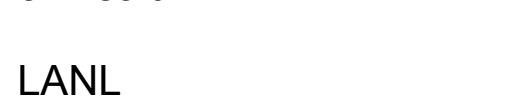 & $\begin{array}{l}\text { ground } \\
\text { squirrel }\end{array}$ & California & 1939 \\
\hline NC_010159.1 & Yersinia pestis & Angola & JCVI & Human & Angola & unknown \\
\hline NC_008150.1 & Yersinia pestis & Antiqua & DOE JGI & Human & Congo & 1965 \\
\hline PRJNA54473 & Yersinia pestis & B42003004 & JCVI & $\begin{array}{l}\text { Marmota } \\
\text { baibacina }\end{array}$ & China & 2003 \\
\hline PRJNA54563 & Yersinia pestis & CA88-4125 & DOE JGI & Human & California & 1988 \\
\hline NC_003143.1 & Yersinia pestis & Co92 & $\begin{array}{l}\text { Sanger Institute } \\
\text { Chinese Center for }\end{array}$ & Human/cat & $\begin{array}{l}\text { Colorado } \\
\text { Yulong }\end{array}$ & 1992 \\
\hline NC_017154.1 & Yersinia pestis & D106004 & $\begin{array}{l}\text { Disease Control and } \\
\text { Prevention }\end{array}$ & $\begin{array}{l}\text { Apodemus } \\
\text { chevrieri }\end{array}$ & $\begin{array}{l}\text { County, } \\
\text { China }\end{array}$ & 2006 \\
\hline NC_017160.1 & Yersinia pestis & D182038 & $\begin{array}{l}\text { Chinese Center for } \\
\text { Disease Control and }\end{array}$ & $\begin{array}{l}\text { Apodemus } \\
\text { chevrieri }\end{array}$ & $\begin{array}{l}\text { Yunnan, } \\
\text { China }\end{array}$ & 1982 \\
\hline
\end{tabular}


Prevention

\begin{tabular}{|c|c|c|c|c|c|c|}
\hline PRJNA54471 & Yersinia pestis & E1979001 & JCVI & $\begin{array}{l}\text { Eothenomy } \\
\text { s miletus }\end{array}$ & China & 1979 \\
\hline PRJNA54469 & Yersinia pestis & F1991016 & $\begin{array}{l}\text { JCVI } \\
\text { The Translational }\end{array}$ & $\begin{array}{l}\text { Flavus } \\
\text { rattivecus }\end{array}$ & China & 1991 \\
\hline PRJNA54399 & Yersinia pestis & FV-1 & $\begin{array}{l}\text { Genomics Research } \\
\text { Institute }\end{array}$ & Prairy dog & Arizona & 2001 \\
\hline PRJNA55339 & Yersinia pestis & India 195 & DOE JGI & Human & India & unknown \\
\hline PRJNA54383 & Yersinia pestis & IP275 & $\begin{array}{l}\text { The Institute for Genomic } \\
\text { Research }\end{array}$ & Human & Madagascar & 1995 \\
\hline & $\begin{array}{l}\text { Yersinia } \\
\text { pseudotuberculos }\end{array}$ & IP31758 & & & & \\
\hline NC_009708.1 & is & & JCVI & Human & Russia & 1966 \\
\hline PRJNA54475 & Yersinia pestis & K1973002 & JCVI & himalaya & China & 1973 \\
\hline PRJNA42495 & Yersinia pestis & & JCVI & Human & an & 1968 \\
\hline NC_004088.1 & Yersinia pestis & KIM10+ & Wisconsin & Human & an & 1968 \\
\hline NC 0172651 & Yersinia nestis & $\begin{array}{l}\text { str. Harbin } \\
35\end{array}$ & $\begin{array}{l}\text { Virginia Bioinformatics } \\
\text { Institute }\end{array}$ & Human & China & 1940 \\
\hline PRJ̄NA54477 & Yersinia pestis & MG05-1020 & JCVI & Human & Madagascar & 2005 \\
\hline & & $\begin{array}{l}\text { Microtus } \\
91001\end{array}$ & $\begin{array}{l}\text { Academy of Military } \\
\text { Medical Sciences, The } \\
\text { Institute of Microbiology }\end{array}$ & Microtus & & \\
\hline NC_005810.1 & Yersinia pestis & & $\begin{array}{l}\text { and Epidemiology, China } \\
\text { Genome Center of }\end{array}$ & brandti & China & 1970 \\
\hline NC_008149.1 & Yersinia pestis & Nep & Wisconsin & Human/soil & Nepal & 1967 \\
\hline PRJNA55343 & Yersinia pestis & Pestoides A & DOE JGI & Human & FSU & 1960 \\
\hline
\end{tabular}




$\begin{array}{llll}\text { PRJNA58619 } & \text { Yersinia pestis } & \text { Pestoides F } & \text { DOE JGI } \\ \text { PRJNA55341 } & \text { Yersinia pestis } & \text { PEXU2 } & \text { ERIC-BRC } \\ \text { PRJNA54479 } & \text { Yersinia pestis } & \text { UG05-045 } & \text { JCVI } \\ & & \text { Z176003 } & \\ \text { PRJNA47317 } & \text { Yersinia pestis } & & \text { CCDC }\end{array}$

$\begin{array}{ll}\text { Human } & \text { FSU } \\ \text { Rodent } & \text { Brazil } \\ \text { Human } & \text { Uganda } \\ \text { Marmota } & \\ \text { himalayana } & \text { Tibet }\end{array}$

unknown 1966

2005

himalayana Tibet

1976 
Table 2 (on next page)

Genetic diversity and dataset length for different species and molecular survey approaches

$\mathrm{Bp}=$ Burkholderia pseudomallei; $\mathrm{Br}=$ Brucella spp.; $\mathrm{Yp}=$ Yersinia pestis 


\begin{tabular}{|c|c|c|c|c|c|c|c|c|c|c|c|}
\hline & & \multicolumn{2}{|c|}{ MLST } & \multicolumn{4}{|c|}{ SNP } & \multicolumn{4}{|c|}{ Genome } \\
\hline & & \multirow[b]{2}{*}{ mean } & \multirow[b]{2}{*}{ variance } & \multicolumn{2}{|c|}{ Chromosome I } & \multicolumn{2}{|c|}{ Chromosome II } & \multicolumn{2}{|c|}{ Chromosome I } & \multicolumn{2}{|c|}{ Chromosome II } \\
\hline & & & & mean & variance & mean & variance & mean & variance & mean & variance \\
\hline \multirow{3}{*}{ Bp } & theta & 36.05 & 127.39 & 7807.03 & 5593613.54 & 4333.68 & 1724029.33 & 4666.60 & 1999005.02 & 2187.99 & 439709.21 \\
\hline & pi & $4.45 \mathrm{E}-03$ & $5.15 \mathrm{E}-06$ & $9.58 \mathrm{E}-02$ & $2.18 \mathrm{E}-03$ & 9.69E-02 & $2.24 \mathrm{E}-03$ & 5.67E-03 & 7.66E-06 & 7.14E-03 & 1.21E-05 \\
\hline & length & 3518.00 & & 31189.00 & & 17313.00 & & 289172.00 & & 108654.00 & \\
\hline \multirow{3}{*}{$\mathrm{Br}$} & theta & 112.58 & 1205.64 & 914.77 & 78109.73 & 234.25 & 5161.72 & 635.85 & 37782.92 & 2046.37 & 390305.58 \\
\hline & pi & $1.00 \mathrm{E}-02$ & $2.46 \mathrm{E}-05$ & 8.01E-02 & $1.54 \mathrm{E}-03$ & $7.66 \mathrm{E}-02$ & $1.43 E-03$ & 7.96E-03 & $1.52 \mathrm{E}-05$ & $1.62 \mathrm{E}-02$ & $6.25 \mathrm{E}-05$ \\
\hline & length & 4409.00 & & 3628.00 & & 929.00 & & 24110.00 & & 36223.00 & \\
\hline \multirow{3}{*}{$Y p$} & theta & 36.17 & 120.42 & 3204.65 & 883301.99 & & & 527.40 & 24020.48 & & \\
\hline & pi & 4.97E-04 & $6.68 \mathrm{E}-08$ & $5.60 \mathrm{E}-02$ & 7.40E-04 & & & $4.55 \mathrm{E}-04$ & 4.94E-08 & & \\
\hline & length & 20498.00 & & 14116.00 & & & & 281149.00 & & & \\
\hline
\end{tabular}


Table 3 (on next page)

Topology distances among phylogenies inferred using different molecular survey approaches

Genome/SNP-I/II = chromosome I or II; R-F Cluster $=$ Robinson-Foulds for rooted trees metric .

Bolded rows show tree comparisons between different chromosomes under the same molecular survey approach 


\begin{tabular}{|c|c|c|c|c|}
\hline \multirow{2}{*}{$\begin{array}{l}\text { Species } \\
\text { B. pseudomallei }\end{array}$} & \multicolumn{2}{|c|}{$\begin{array}{c}\text { Tree } \\
\text { Comparisons } \\
\end{array}$} & \multirow{2}{*}{$\begin{array}{c}\text { Matching } \\
\text { Cluster }\end{array}$} & \multirow{2}{*}{$\begin{array}{c}\begin{array}{c}\text { R-F } \\
\text { Cluster }\end{array} \\
16\end{array}$} \\
\hline & mlst & snp-I & & \\
\hline B. pseudomallei & mlst & snp-II & 162 & 17 \\
\hline B. pseudomallei & mlst & genome-I & 149 & 18 \\
\hline B. pseudomallei & mlst & genome-II & 116 & 18 \\
\hline B. pseudomallei & snp-I & snp-II & 33 & 7 \\
\hline B. pseudomallei & snp-I & genome-I & 56 & 17 \\
\hline B. pseudomallei & snp-I & genome-II & 91 & 17 \\
\hline B. pseudomallei & snp-II & genome-I & 47 & 19 \\
\hline B. pseudomallei & snp-II & genome-II & 72 & 16 \\
\hline B. pseudomallei & genome-I & genome-II & 63 & 14 \\
\hline Brucella spp. & mlst & snp-I & 34 & 5 \\
\hline Brucella spp. & mlst & snp-II & 10 & 1.5 \\
\hline Brucella spp. & mlst & genome-I & 73 & 4.5 \\
\hline Brucella spp. & mlst & genome-II & 56 & 5 \\
\hline Brucella spp. & snp-I & snp-II & 24 & 5.5 \\
\hline Brucella spp. & snp-I & genome-I & 61 & 5.5 \\
\hline Brucella spp. & snp-I & genome-II & 40 & 5 \\
\hline Brucella spp. & snp-II & genome-I & 63 & 5 \\
\hline Brucella spp. & snp-II & genome-II & 50 & 4.5 \\
\hline Brucella spp. & genome-I & genome-II & 67 & 7.5 \\
\hline Y. pestis & mlst & snp & 223 & 13.5 \\
\hline Y. pestis & mlst & genome & 103 & 8 \\
\hline Y. pestis & snp & genome & 124 & 8.5 \\
\hline
\end{tabular}




\section{Table 4(on next page)}

Trait-phylogeny association statistics

Significant associations ( $p$ value $<0.05$ ) were found between traits (sampling

location/host/time) and phylogenies inferred by using different data approaches. Association index (Al); Parsimony Score (PS); genome/SNP-I/II = chromosome I or II 
2

\begin{tabular}{|c|c|c|c|}
\hline \multirow[t]{3}{*}{ Statistic } & \multicolumn{3}{|c|}{ Trait } \\
\hline & \multicolumn{3}{|c|}{ Sampling Location } \\
\hline & B. pseudomallei & Brucella spp. & Y. pestis \\
\hline Al & $\begin{array}{l}\text { MLST, genome-I, } \\
\text { genome-II, SNP-I, } \\
\text { SNP-II }\end{array}$ & $\begin{array}{l}\text { MLST, genome-I, } \\
\text { genome-II, SNP- } \\
\text { I, SNP-II }\end{array}$ & $\begin{array}{l}\text { MLST, genome, } \\
\text { SNP }\end{array}$ \\
\hline PS & $\begin{array}{l}\text { MLST, genome-I, } \\
\text { genome-II, SNP-II }\end{array}$ & MLST, SNP-II & $\begin{array}{l}\text { MLST, genome, } \\
\text { SNP }\end{array}$ \\
\hline Al & $\begin{array}{l}\text { B. pseudomallei } \\
\text { none }\end{array}$ & $\begin{array}{l}\quad \text { Host } \\
\text { Brucella spp. } \\
\text { MLST, genome-I, } \\
\text { genome-II, SNP- } \\
\text { I, SNP-II }\end{array}$ & $\begin{array}{l}\text { Y. pestis } \\
\text { genome, SNP }\end{array}$ \\
\hline PS & none & $\begin{array}{l}\text { MLST, genome-I, } \\
\text { genome-II, SNP- } \\
\text { I, SNP-II } \\
\quad \text { Time }\end{array}$ & none \\
\hline Al & $\begin{array}{l}\text { genome-I, } \\
\text { genome-II }\end{array}$ & none & genome \\
\hline PS & none & none & genome \\
\hline
\end{tabular}

